\title{
Introduction: Kingship and Political Legitimacy in the Persianate World
}

\author{
Kazuo Morimoto \\ The University of Tokyo \\ morikazu@ioc.u-tokyo.ac.jp
}

\section{Keywords}

kingship - legitimation - political authority - political legitimacy - Persianate world

The development of kingship and political legitimacy in the Persianate world is marked by its synthesis and entangling of many different religious, philosophical, and intellectual discourses of varying ethnic and geographical origins.* This is all the truer with respect to the periods after 1258 , where the authority of the caliphs in Baghdad was no longer existent and Mongol dominance brought about new types of authority and legitimacy. The ways in which Timur's authority was characterized during his own time and during the time of his immediate descendants demonstrate amply the complexity involved in the processes of political legitimation in the "post-Baghdad" (or "post-1258") period: these included, among others, Chengizid (albeit indirectly), astrologically-ordained, and even 'Alid legitimacies (Mano; Woods; Chann; Moin, ch. 2; Morimoto). In the meantime, vigorous research in recent years has elucidated the evolution of the processes of legitimation in the early-modern Persianate world, where, among others, new modes of interaction between politics and religion were manifested in widespread claims to sacral kingship. ${ }^{1}$ Attempts are already being made to look at the several centuries of the post-Baghdad period as a

\footnotetext{
* I would like to thank Dr. Evrim Binbaş for his comments on an earlier version of this introduction. This introduction was finished during a research opportunity provided to me by Alexander Humboldt Kolleg for Islamicate Intellectual History. I thank Professor Judith Pfeiffer for her kind invitation.

1 For an overview of this research trend, see Melvin-Koushki.
} 
longue durée and thereby elucidate different threads of evolution that connected the mid-thirteenth century with the early modern period. ${ }^{2}$

Problematically, the prevalent narrative of the historical development of Islamicate political thought, which still remains heavily Arab- and pre-1258centric, does not cover and explain such post-Baghdad developments in the area of kingship and political legitimacy properly. ${ }^{3}$ The new legitimation strategies of kingship that developed in the post-Baghdad Persianate world are highly complex and must be analyzed holistically in their own terms. In effect, they constitute a distinct and rewarding field of research - one that not only lies at the heart of the study of Persianate societies but promises to reconfigure our current narratives of Islamicate political thought, practices, and institutions more generally. ${ }^{4}$

The symposium "Kingship and Political Legitimacy in the Persianate World" showcases some of the latest findings in this crucial field of research. The four articles contained here address the subject from different angles, ranging from patronage of courtly literary activities as a means of building political legitimacy (Otsuka); to the elucidation of the confessional environment for the purpose of a better understanding of a dynasty's claim to legitimacy (Binbaş); to the role that language played in the choice of a legitimacy type claimed by or for a dynasty (Ogura); to the gradual evolution of a legitimation strategy adopted by a dynasty at its genesis (Kondo). In addition, two of the contributions provide valuable insights into the question of the place of Persian language and literature in the multi-lingual societies of the Persianate world, befitting their publication in the Journal of Persianate Studies (Otsuka and Ogura). On the temporal front, the time periods discussed in the contributions range from the early fourteenth to the late eighteenth centuries. Thus, in terms of both the topics and the periods it covers, this symposium goes far beyond the concerns of currently-prevalent research focusing on sacral kingship from the fall of Baghdad to the early modern period, thereby demonstrating the breadth and richness of the subject of kingship and political legitimacy in the postBaghdad Persianate world.

2 See Brack. Of course, many of the elements that came together to form a new configuration originated far earlier and need to be studied in their own terms; see, e.g., Chann.

3 See, e.g., Crone, who is arguably justified not to discuss the post-Baghdad development in her book as the word "medieval" in the book's title covers only the period until 126o (i.e., the Battle of 'Eyn Jālut) (413). It is, however, possible to question why the "medieval" period should terminate at that point, instead of, say, the mid-fifteenth century (conquest of Constantinople) or the early sixteenth century (the beginning of the era of the three "Gunpowder Empires").

4 Arjomand has also repeatedly highlighted the importance of the research on what he calls "Persian kingship" or "Persianate kingship" for Persianate studies at large; see, e.g., idem 2010; 2019 . 
Osamu Otsuka's contribution focuses on the literary life of the court of Nosrat al-Din Ahmad (r. 1296-1331/2) of the Hazaraspids (or, the atabegs of Lor-e Bozorg). Otsuka begins by enumerating Persian literary works composed under the patronage of Nosrat al-Din and demonstrates the significance of Idhaj (present-day Izeh), the dynasty's capital, as a center of Persian literary activity at the time. Otsuka finds that Nosrat al-Din is represented in those Persian works as a descendant of the mythical Kayanids who also embodies the ideal features of both a Persian and an Islamic ruler. Furthermore, he points out that even the Kayanids themselves are depicted in those works as having been monotheistic. Based on these findings, Otsuka argues that Nosrat al-Din's patronage to Persian literature was itself linked to the Hazaraspids' claim to Kayanid descent and aimed at propagating it. Having thus unearthed a littleknown flowering of Persian literary life in the middle of the Zagros Mountains, Otsuka suggests that more attention be paid to local dynasties' patronage of Persian literature during the Il-khanid period. Since Otsuka sees in the case of Nosrat al-Din's patronage a self-aggrandizing claim to "the mantle of a legitimate Persian ruler" by a vassal of the Turco-Mongol Il-khanids, Otsuka's suggestion is clearly meant to call for a reappraisal of the self-identification, self-representation, and self-legitimation by the local dynasties of the Il-khanid period along the same line.

Evrim Binbaş discusses the confessional orientations of the Qara Qoyunlu, especially the appanage rulers in Iraq, in his study. Shāh Mohammad b. Qara Yusof, who ruled Iraq between 1411 and 1433, is accused of "reprehensive" religious beliefs in contemporary and near-contemporary Muslim sources. But what did Shāh Mohammad really believe? Various material and textual evidence leads Binbaş to conclude that the answer is Christic ideas- that is, the belief that positions Jesus as superior to the other Islamic prophets. The existence of a belief in the notion of a "hidden king," à la Hidden Imam, among the population of fifteenth-century Baghdad is one such piece of evidence. The unearthing of these unnoted ideas and beliefs reveal both the complexity of the confessional situation of the time and the insufficiency of our knowledge. Binbaş points out that the discussion of "Turkman religiosity," including that of the Qara Qoyunlu, has been circumscribed by the teleological concern that aim at explaining the phenomena of the sixteenth century and later, above all, the establishment of the Safavid state and the emergence of the Alevis. Binbaş's pronouncement is clear and convincing: the religious situation of the fifteenth century must be studied on its own contextual terms. This article makes an important contribution to the ongoing discussion of the kingship and political legitimacy in the Persianate world in which elements of continuity and gradual evolution from the Mongol period (if not earlier) to early modern times have received greater focus. If the 
fifteenth century had its own terms, then the other centuries must have had their own, too.

Satoshi Ogura's article takes up the case of Kashmir from the fourteenth to the late sixteenth centuries. Kashmir since the establishment of the Shahmirid dynasty in 1339, with both Persian and Sanskrit used at the court and in society and with its mixed population of Muslims and non-Muslims, was a suitable place for examining the entanglement of the Sanskrit-based and the Persianbased cosmopolitan cultures in South Asia. Ogura begins by outlining the political and religio-cultural history of Kashmir from the early eighth to the late sixteenth centuries and then explains the intensive bilingualism both at the court and in society during the Shahmirid period. As for the representation of the Shahmirid sultans in various types of sources, Ogura's main finding is that the type of legitimacy attached to those rulers in a text depended on the language in which the text was written. While the Indic legitimacy, derived from the Mahäbhärata and Śaivism, was attached to those sultans in literary sources and inscriptions written in Sanskrit, the coins struck by the Shahmirids with Arabo-Persian legends presented the sultans as deputies of the 'Abbasid caliphs in Cairo. Lastly, Ogura demonstrates how one and the same royal practice could be interpreted in starkly different ways by the two interpretive communities, linked respectively to Persian and Sanskrit, through an examination of the account of the sun-worshipping by Akbar (who annexed Kashmir to Mughal domains in 1586) in a Kashmiri Sanskrit text and comparing it with those of Muslim authors.

Lastly, Nobuaki Kondo traces the rise of Āqā Mohammad Khān/Shāh with special reference to the changing modes of legitimation attempts adopted by the Qajar ruler's camp as it gradually established its power over Iran. Kondo first establishes the chronology of the rise of Āqā Mohammad and identifies the coronation in 1796 at Tehran as the most important event in the process, when seen from the vantage point of legitimation. Kondo then turns to the coins and documents issued by Āqā Mohammad. Kondo's discussion deals with such varied elements as coins' legends and sizes, as well as the edicts' toghräs (opening formulae) and seals (in terms of their locations and designs), so the findings he gets from each of them are not necessarily uniform. The general trend, however, is unmistakable. While, before his coronation, Āqā Mohammad followed the precedents of earlier post-Nader rulers in styling those trappings of political legitimacy, he began to assert his status as the sovereign of Iran - on par with the Safavids - following his coronation (and the ensuing conquest of Khorasan). Kondo also discusses a manner of political legitimation to which the early Qajars did not pay attention: legitimating political claims through genealogical descent. Kondo points out that the Qajars did 
not even establish an official genealogy and presents sources that indicate the Qajars' indifference to elaborating such a genealogy for themselves. The Qajars' interest, attestable in those manuscripts, is limited to juxtaposing themselves with other prestigious dynasties, whether Islamic or pre-Islamic, without ever elaborating on the lineages of those dynasties.

This symposium is first and foremost an output of the joint research project "Kingship and Legitimacy of Islamic Dynasties," led by Nobuaki Kondo and supported by the Japan Society for the Promotion of Science (Grant-in-Aid for Scientific Research [A] 15Ho1895; April 2015-March 2020). An earlier version of Binbaş's contribution was presented at the workshop "State, Religion, and Authority in the Post-Mongol Persianate World and Beyond" at the University of Tokyo in March 2017, during his trip to Japan at the invitation of the project. Likewise, the three other articles are based on the presentations made on the two-panel series "Forms of Political Authority in the Post-Mongol Persianate World, I \& II," co-organized by Kazuo Morimoto and Nobuaki Kondo as part of the project's program at the Eighth Biennial Congress of the Association for the Study of Persianate Societies (March 2018, Ilia State University, Tbilisi). I would like to express my sincere gratitude to the JSPS for its financial support and thank the other participants of the Tokyo workshop and the Tbilisi two-panel series for their contributions. Additionally, the guest-editing process of this symposium was supported by another joint research project under the aegis of the JsPs, "Muslim Discourses Surrounding the Prophet Muhammad's Kinfolk," led by myself (Grant-in-Aid for Scientific Research [B] 19Ho1317; April 2019March 2023). I would like to express my gratitude to the members of the project who agreed with me to allocate part of the project's resources to this work.

In a sense, this special issue also showcases Japanese contributions to Persianate studies. I trust that the existence of solid Japanese scholarship on the Persianate world has long been acknowledged by colleagues in the field. It appears, however, still questionable as to how immediate its presence has been felt as something provoking serious conversation. I hope that this symposium will contribute to the multiplying and widening of avenues of such conversation which, no doubt, will help Persianate studies advance further on.

\section{Bibliography}

S. A. Arjomand, "Legitimacy and Political Organisation: Caliphs, Kings and Regimes," in R. Irwin, ed., The New Cambridge History of Islam, vol. 4, Islamic Cultures and Societies to the End of the Eighteenth Century, Cambridge, 2010, pp. 223-73, DOI 10.1017/CHOL9780521838245.009. 
S. A. Arjomand, "Persianate Islam and the Secularity of Kingship," in Companion to the Study of Secularity, Humanities Centre for Advanced Studies "Multiple SecularitiesBeyond the West, Beyond Modernities," Leipzig, 2019, pp. 1-12; online: http://www .multiple-secularities.de/publications/companion/css_arjomand_persianate kingship.pdf (accessed: 07 October 2019).

J. Brack, "Theologies of Auspicious Kingship: The Islamization of Chinggisid Sacral Kingship in the Islamic World," Comparative Studies in Society and History 60.4 (2018), pp. 1143-71, DOI 10.1017/Soo10417518000415.

N. S. Chann, "Lord of the Auspicious Conjunction: Origins of the Șähib-Qirān," Iran and the Caucasus 13.1 (2009), pp. 93-110, DOI 10.1163/160984909X12476379007927.

P. Crone, Medieval Islamic Political Thought, New Edinburgh Islamic Surveys, Edinburgh, 2004.

E. Mano, "Amīru Timūru Kyuregen: Timūruke no Keifu to Timūru no Tachiba (Amir Tīmūr Kürägän: The Timurid Genealogy and Timur's Position)," Tōyōshi-Kenkyū 34.4 (1976), pp. 591-615, DOI 10.14989/153603 (Japanese).

M. Melvin-Koushki, "Early Modern Islamicate Empire: New Forms of Religiopolitical Legitimacy," in A. Salvatore, R. Tottoli, and B. Rahimi, eds., The Wiley Blackwell History of Islam, Oxford, 2018, pp. 351-75, DOI 10.1002/9781118527719.ch17.

A. A. Moin, The Millennial Sovereign: Sacred Kingship and Sainthood in Islam, South Asia Across the Disciplines, New York, 2012.

K. Morimoto, "An Enigmatic Genealogical Chart of the Timurids: A Testimony to the Dynasty's Claim to Yasavi-'Alid Legitimacy?" Oriens 44.1-2 (2016), pp. 145-78, DOI 10.1163/18778372-04401007.

J. E. Woods, “Timur's Genealogy," in M. M. Mazzaoui and V. B. Moreen, eds., Intellectual Studies on Islam: Essays Written in Honor of Martin B. Dickson, Salt Lake City, 199o, pp. $85^{-125}$. 